\title{
Temporal and spatial variation of Botryosphaeriaceae associated with Acacia karroo in South Africa
}

Fahimeh JAMI ${ }^{a}$, , Bernard SLIPPERS ${ }^{b}$, Michael J. WINGFIELD ${ }^{a}$, Mattheus T. LOOTS ${ }^{c}$, Marieka GRYZENHOUT ${ }^{d}$

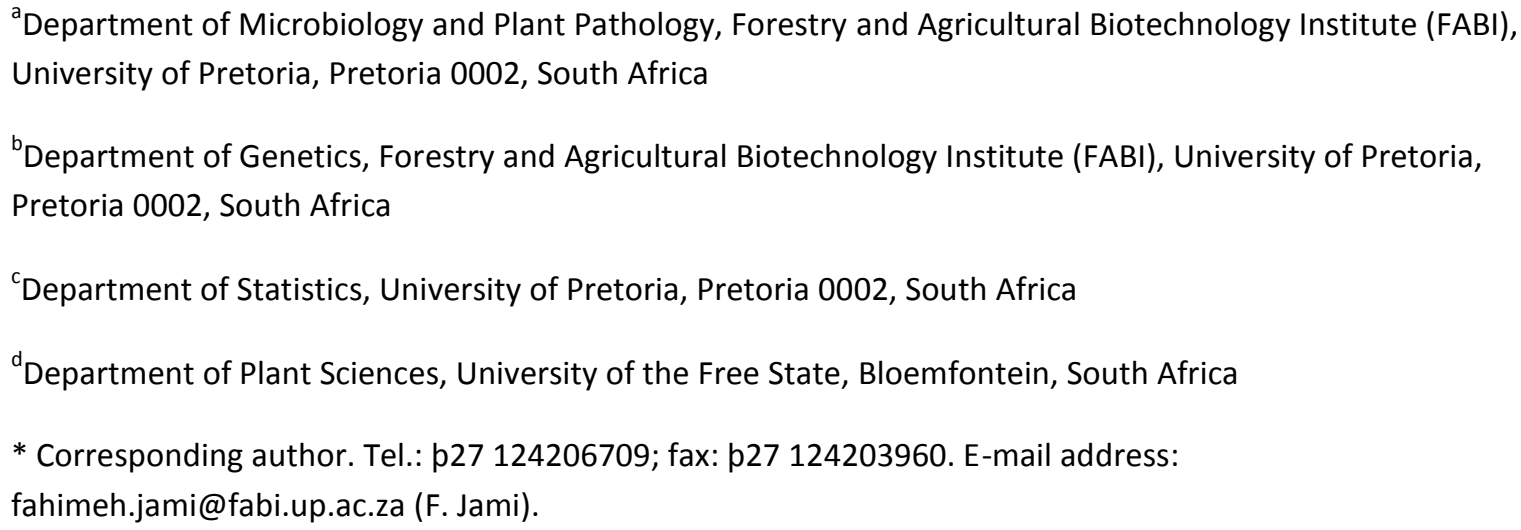

\section{Abstract}

The Botryosphaeriaceae are common and diverse members of fungal communities infecting woody plants. They are also increasingly being used as model organisms to understand patterns in the global movement of latent pathogens. The aim of this study was to consider the species richness of the Botryosphaeriaceae associated with the native Acacia (Vachellia) karroo across South Africa, and the variation of species at specific local sites over time. The diversity of these fungi associated with different tissues of this host plant was also considered. These questions were addressed by sampling healthy A. karroo from 23 sites in South Africa and by more intensive hierarchical sampling conducted at 40 sites in one area over $3 \mathrm{yr}$. In total, 13 species of the Botryosphaeriaceae were identified, including seven that were isolated only from the more intensively sampled area. There was a clear geographical influence, with some species occurring only in some parts of the country. Significant variation in the species richness over time for the intensively sampled area was found and there was no evidence of tissue specificity for this group of fungi in leaves, branches and branchlets. Results of pathogenicity trials showed highly variable lesion sizes for the isolated species in comparison to the control, with Sphaeropsis variabilis, Lasiodiplodia theobromae and Neofusicoccum australe being the most pathogenic. The overall results revealed a rich diversity of Botryosphaeriaceae on this native host, which varied significantly both geographically and on individual trees, even in the absence of obvious disease.

Keywords:

Acacia karroo ; Biogeography ; Botryosphaeriaceae ; Host association ; Spatial variation 


\section{Introduction}

The Botryosphaeriaceae (Ascomycota) is one of the most widespread fungal groups infecting woody plants. These fungi are well-known as latent fungal pathogens that typically cause disease only when host plants are under stress (Slippers and Wingfield, 2007). Botryosphaeriaceae can infect their hosts via both natural openings or wounds and can persist for long periods within healthy plant parts, including woody tissues of stems, branches, twigs, and leaves. Many of the well-studied species are also known to infect a wide range of plants. These characteristics make the Botryosphaeriaceae increasingly important pathogens of trees globally, because they are easily transported between regions, can infect a range of new hosts and are of particular concern under scenarios of increasing stress on plants due to climate change or human disturbance.

Recent studies on native and non-native Acacia species have revealed a wide diversity of Botryosphaeriaceae in South Africa. This includes five previously known (Jami et al., 2013; Slippers et al., 2014) and 13 newly described species (Jami et al., 2012; Slippers et al., 2014). Acacia karroo (=Vachellia karroo) is one of the most commonly occurring native tree species in South Africa with a wide distribution across large areas of the country (VanWyk and VanWyk, 1997). Botryosphaeriaceae are known to infect $A$. karroo and 11 species have been found on this host in different parts of South Africa (Jami et al., 2012, 2013; Slippers et al., 2014). A number of Botryosphaeriaceae have also been found on other species of Acacia such as the non-native $A$. mearnsii (Roux et al., 1997), and native $A$. tortilis, $A$. erioloba and A. mellifera (Slippers et al., 2014). Studies such as these, and others considering native hosts in South Africa, provide baseline information for future studies on changes, new introductions and overlaps between native and non-native host species. Unfortunately, many previous studies have included few sampling locations, a limited number of tissue types and tend not to have been repeated at the same locations over time. It is thus not clear how representative these samples are of the Botryosphaeriaceae communities or how comparable results from the different studies might be.

Apart from those on A. karroo, various other studies on the Botryosphaeriaceae in South Africa have identified 12 genera, including at least 48 species (including unpublished work by the authors), from different native and non-native hosts. These hosts include native woody plants such as Syzygium cordatum (Pavlic et al., 2007), Pterocarpus angolensis, Terminalia catappa (Begoude et al., 2010; Mehl et al., 2011), and species of Leucadendron, Leucospermum and Protea (Denman et al., 2003; Marincowitz et al., 2008b). Forty of the Botryosphaeriaceae species occur on these native plants, of which 10 overlap with nonnative trees such as Pinus spp., Eucalyptus spp. and fruit trees including peach, pear, almond, apple, plum, nectarine, apricot, and grapevine (Swart and Wingfield, 1991; Smith et al., 2001; Damm et al., 2007; Slippers et al., 2007). There is clearly substantial overlap between the various hosts, but variable sampling efforts make it difficult to draw strong conclusions regarding host specificity. 
The above-mentioned studies on the Botryosphaeriaceae have shown a wide geographical distribution across South Africa of this group of fungi, which has been detected in all sampled areas. The results also suggest there could be unique patterns of diversity of the Botryosphaeriaceae in different locations. Some species appear to be widely distributed such as Botryosphaeria dothidea and Neofusicoccum parvum (Roux et al., 1997; Smith et al., 2001; Denman et al., 2003; Slippers et al., 2004b; Van Niekerk et al., 2004; Pavlic et al., 2007; Begoude et al., 2010; Jami et al., 2014), while others are found only in one or a small number of locations.

Tissue type has been shown to affect species diversity of endophytes (Taylor et al., 1999; Shamoun and Sieber, 2000; Gond et al., 2007; Huang et al., 2008; Kharwar et al., 2008; Yuan et al., 2009; Gazis and Chaverri, 2010; Mishra et al., 2012). For example, Pseudocercospora $\mathrm{sp}$. was isolated as an endophyte from leaves of Tapirira guianensis, while it was never isolated from the stems of that host (de Abreu et al., 2010). In contrast, Stagonospora sp. was found in stems of $T$. guianensis, while it was absent from the leaves. The Botryosphaeriaceae occur on a variety of tree tissues including leaves, branches, twigs, seeds and fruits. No studies have, however, been undertaken to consider potential tissue specificity or preference of Botryosphaeriaceae species.

The aim of this study was to conduct a comprehensive survey of the endophytic Botryosphaeriaceae infecting $A$. karroo throughout South Africa. The data were then used to determine possible patterns of geographic diversity of Botryosphaeriaceae distribution on A. karroo. In the greater Tshwane Metropolitan area (Pretoria, Gauteng Province), the surveys were conducted over $3 \mathrm{yr}$ to assess the temporal changes in dominance of the species obtained. The diversity of these fungi was also compared among different tissues (leaves, branches, branchlets and seeds) of $A$. karroo in samples from the Tshwane Metropolitan area. This study focused only on healthy looking trees in order to avoid potential variation in infection levels over the study period. The pathogenicity of the isolated Botryosphaeriaceae was also tested to gain some insight into the potential of these species to cause disease.

\section{Materials and methods}

\section{Isolate collection}

Samples were collected randomly from 318 healthy A. karroo trees in a countrywide survey (22 sites) of South Africa in 2010 (Fig 1). One branch ( $0.5 \mathrm{e} 1 \mathrm{~cm}$ diameter) per tree was cut and all samples were placed in paper bags and taken to the laboratory for processing after storage at 4 a for 1 week. From each branch, 12 pieces $(0.5 \mathrm{~cm})$ were randomly selected, surface-disinfested in $10 \%$ hydrogen peroxide for $2 \mathrm{~min}$, and rinsed three times in sterile water. All branch samples were placed on $2 \%$ malt extract agar (MEA; Biolab, Midrand, South Africa) in Petri dishes with four samples per plate. Petri dishes were incubated at 24 ? $\mathrm{C}$ for $7 \mathrm{~d}$ and fungal growth from each wood sample showing cultural morphology 


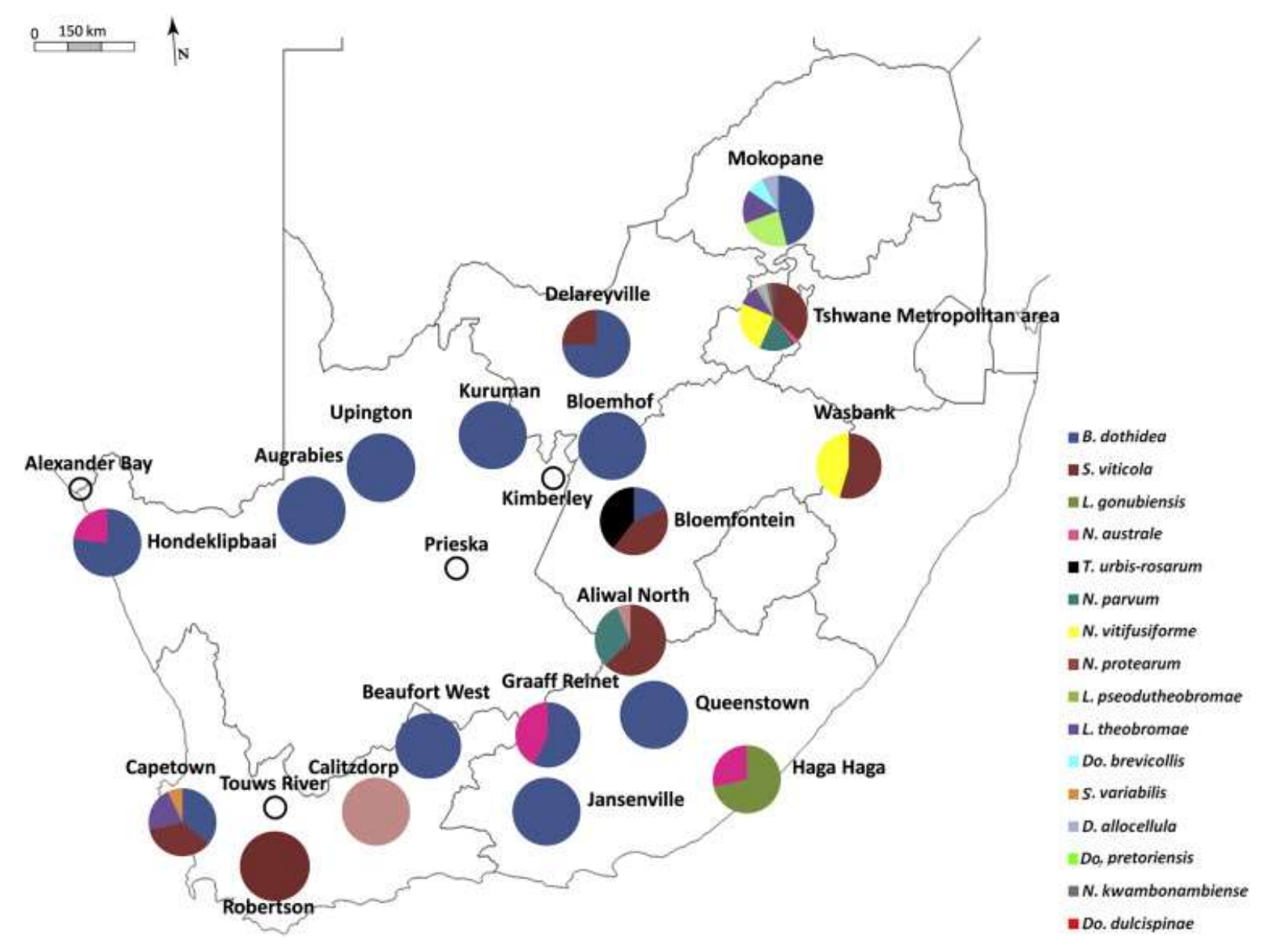

Fig 1 : Species diversity of Botryosphaeriaceae in South Africa. Pie charts illustrate the species richness in each sampled site and black circles indicate sites without species

characteristics of the Botryosphaeriaceae (fast growing, white to black cultures with fluffy aerial hyphae) was transferred to fresh MEA plates. After $4 \mathrm{e} 5 \mathrm{~d}$, all isolates showing typical growth were transferred to $15 \%$ water agar (WA) to make single hyphal tip sub-cultures. These isolates are maintained in the Culture Collection (CMW) of the Forestry and Agricultural Bio-technology Institute (FABI), University of Pretoria, Pretoria, South Africa.

To assess possible variation in Botryosphaeriaceae diversity over time, one accessible region, namely the Tshwane Metropolitan area (Pretoria, Gauteng Province), with 40 local sites for sampling, was selected to conduct sampling over 3 yr. Samples were collected from 2008 to 2010 in early winter from the healthy A. karroo trees at these 40 local sites across diverse areas in Tshwane Metropolitan. Trees were either in planted gardens and parks or originated from natural regeneration within or outside the city border. One tree was randomly selected per local site for sampling. Three healthy branches (w0.5e1 cm diameter) per tree were cut and branches including leaves and thorns (in some cases with attached seeds) were collected from 40 trees in the first and second years and 20 trees for 20 randomly selected sites in the third year. The same locations were used, and where possible, the same trees were sampled in successive years. From each branch, 12 pieces $(0.5$ $\mathrm{cm}$ ) from the main part of the branch, 12 pieces from branchlets, 12 leaves and 12 thorns 
were randomly selected, surface-disinfested in $10 \%$ hydrogen peroxide for $2 \mathrm{~min}$, and rinsed three times in sterile water. All samples were placed on $2 \%$ MEA (Biolab, Midrand, South Africa) in Petri dishes with four samples per plate. One hundred seeds were selected from the sampled branches, surface-disinfested in $10 \%$ hydrogen peroxide for $2 \mathrm{~min}$, and rinsed three times in sterile water. Fifty of the seeds were crushed and placed on $2 \%$ MEA, while the remaining 50 were placed on the $2 \%$ MEA as whole seeds.

\section{DNA sequencing}

Isolates were initially grouped based on culture morphology (growth rate, color of the aerial mycelium and medium dis-coloration) using the same criteria as reported by Jami et al.(2012). DNA was extracted from the mycelium of $5 \mathrm{~d}$ old single hyphaltip cultures (Lee and Taylor, 1990) of three representatives from each morphological group. Sequence data were obtained for the internal transcribed spacer region of the ribosomal RNA (rRNA) operon using primers ITS-1 (Gardes and Bruns, 1993) and ITS-4 (White et al., 1990) and the translation elongation factor 1-a (TEF-1 $\alpha$ ) gene using primers EF1-728F and EF1-986R (Carbone and Kohn, 1999) as used in previous studies on Botryosphaeriaceae (Slippers et al., 2004a; Luque et al., 2005; Phillips et al., 2005; Burgess et al., 2006a; Piskur et al., 2011). The PCR reaction mixture, $P C R$ conditions and visualization were as described by Jami et al. (2012). The amplified PCR fragments were purified with Sephadex (Sigma, Steinheim, Germany) and sequenced using BigDye terminator cycle sequencing kits (PerkineElmer Applied Biosystems, Foster City, California, USA) in both directions, with the same primers used for the PCR reactions. PCR products were sequenced using an ABI 3730 sequencer (PerkineElmer Applied Biosystems).

Sequences of the isolates were edited using Vector NTI 11 software (Lu and Moriyama, 2004). Additional sequences for phylogenetic analysis were obtained from nucleotide BLAST comparisons (blastn) with DNA sequences for relevant Botryosphaeriaceae species previously published from Gen-Bank (http://www.ncbi.nlm.gov) and used in the analyses. The resulting data matrices for each gene region were rooted to Pseudofusicoccum stromaticum following the example of Phillips et al. (2008). The data matrices were aligned online using MAFFT version 6 (Katoh et al., 2005) and checked manually for alignment errors in MEGA version 4 software (Tamura et al., 2007).

Phylogenetic analyses of sequence data for Maximum Parsimony (MP) and Maximum Likelihood (ML) were made using PAUP 4.0b10 (Swofford, 2001). Maximum parsimony (MP) genealogies for single genes were constructed with the heuristic search option (100 random taxa additions, tree bisection and reconstruction or TBR) in PAUP. All characters were unordered and of equal weight and gaps were treated as missing data. Branches of zero length were collapsed and all multiple, equally parsimonious trees were saved. The robustness of the tree(s) obtained was evaluated by 1000 bootstrap replications. Congruence between the different datasets was tested using the Partition Homogeneity Test (PHT) in PAUP (Phylogenetic Analysis Using Parsimony) version 4.0b10 (Farris et al., 
1995; Huelsenbeck et al., 1996), with the uninformative characters removed before analysis. Other measures such as tree length (TL), consistency index $(\mathrm{Cl})$, rescaled consistency index $(\mathrm{RC})$, and the retention index (RI)(Hillis and Huelsenbeck, 1992) were recorded. For ML analyses, the best nucleotide substitution models for each dataset were found separately with Modeltest 3.7 (Posada and Buckley, 2004), and for the combined dataset. The ML analyses were performed in PAUP 4.0b10 and confidence levels were deter-mined with 1000 bootstrap replications.

\section{Statistical analyses of species richness}

The data for species richness were pooled across local sites, and were used in all statistical analyses using $R$ (v3.1). A significance level of 0.01 was used for all analyses. Fisher's exact test (Fisher, 1970) was used to compare the collections over 3 yr from Tshwane Metropolitan area (2008: $n=40,2009: n=40,2010: n=20)$.

The species richness was first compared between years and then among the different tissue types (leaves, branches and branchlets) sampled. Comparisons among species in each tissue were done by means of a contingency table having species richness and tissue as row and column entries (performed by year), followed by the same analysis where the roles of tissue and year were reversed. The average minimum and the average maximum monthly temperature, precipitation, humidity and sunlight hour data were obtained from the South African Weather Service (Pretoria station), then the data were averaged across months for each year (Table 1). These data were used to consider the variation of these climatic factors among sampling years and their possible effect on species richness. To determine the variation of monthly temperatures (minimum and maximum), monthly precipitation, humidity and sunlight hours across the three years, a k-sample Anderson Darling test was performed, using the "k-samples" package (Scholz and Zhu, 2012) in R. To determine whether species richness was influenced by the number of samples, species richness rarefaction curves were calculated via iNEXT online (Hsieh et al., 2013).

Table 1 : The average of climate data obtained for the Tshwane
Metropolitan (Pretoria, Gauteng) sites for the three years of
sampling
\begin{tabular}{|l|r|r|r|}
\hline & & & \\
\hline Climate factors & 2008 & 2009 & 2010 \\
\hline Maximum temperature & 23.9 & 24.51 & 24.5 \\
\hline Minimum temperature & 11.25 & 11.62 & 11.54 \\
\hline Rainfall (mm) & 765.6 & 588.4 & 801.1 \\
\hline Daily sunlight (hour) & 8.1 & 8.2 & 8 \\
\hline Humidity (\%) & 69.58 & 70 & 71.58 \\
\hline
\end{tabular}




\section{Pathogenicity tests}

One-year-old A. karroo seedlings ranging in height from 70 to $110 \mathrm{~cm}$ and stems of $0.7 \mathrm{e} 1.5$ $\mathrm{cm}$ in diameter were maintained in a greenhouse at 26 and watered once daily. The plants were grown in a 1:2:4 mixture of river sand, red top soil and pine bark potting medium in 5 I plastic bags. Two to three isolates of each Botryosphaeriaceae species identified based on phylogenetic analyses were selected and each isolate was inoculated on 10 trees with one additional tree in each replication inoculated with sterile medium as a control. Inoculations were made following the technique used by Jami et al.(2013). In total, 37 isolates were inoculated on 370 plants, with an additional 37 plants inoculated as negative controls. Lesion lengths were measured 6 weeks after inoculation. Variation in lesion length was analyzed using the Kruskal-Wallis Rank Sum test, in the statistical package $\mathrm{R}$, version 3.1.1. The data from an earlier study (Jami et al., 2013) were included in the analyses, which brought the total number of isolates considered to 44 .

To confirm Koch's postulates, one plant was chosen from those inoculated with each isolate (in total 37 plants) for re-isolation, as well as for 13 control plants. A small sample of tissue was cut from the lesions including the inoculation points, surface-disinfested with $10 \%$ hydrogen peroxide for $2 \mathrm{~min}$, and rinsed three times in sterile water. The tissue samples were plated onto $2 \%$ malt extract agar and incubated at 24 ? $\mathrm{C}$ for $7 \mathrm{~d}$ after which isolates were identified based on morphological characters.

\section{Results}

Isolate collections

In total, 404 Botryosphaeriaceae isolates were collected from A. karroo branches from 18 sites across South Africa (excluding Tshwane Metropolitan area). Of the sampled trees ( $n=$ 278), 31 \% yielded isolates. With the exception of four sites, namely Kimberley, Prieska, Alexander Bay (in Northern Cape Province) and Touws River (in Western Cape Province), isolates were obtained from all sites across the geographical range sampled (Table 2).

A total of 267 isolates of Botryosphaeriaceae were obtained over the $3 \mathrm{yr}$ sampling period in the Tshwane Metropolitan area. Of these, 110 isolates were obtained in 2008 (26 from leaves, 52 from stems, 32 from branches), 93 isolates in 2009 (44 from leaves, 21 from stems, 28 from branches), and 64 isolates in 2010 (60 from leaves and four from branches). These isolates were found on $55 \%, 45 \%$ and $50 \%$ of sampled trees over the $3 \mathrm{yr}$, respectively. No Botryosphaeriaceae species were isolated from seeds and thorns during these 3 yr. 


\begin{tabular}{|c|c|c|c|c|c|c|c|c|c|c|c|c|c|c|c|c|c|}
\hline & $\begin{array}{l}\text { cNo. } \\
\text { T }\end{array}$ & $\begin{array}{l}\text { B } \\
\text { D }\end{array}$ & $\begin{array}{l}\mathrm{D} \\
\mathrm{A}\end{array}$ & $\begin{array}{l}\text { Do } \\
\text { B }\end{array}$ & $\begin{array}{l}\text { Do } \\
\text { D }\end{array}$ & $\begin{array}{l}\mathrm{L} \\
\mathrm{G}\end{array}$ & LT & $\begin{array}{l}\text { LP } \\
t\end{array}$ & $\begin{array}{l}\mathrm{N} \\
\mathrm{A}\end{array}$ & $\begin{array}{l}\mathrm{N} \\
\mathrm{K}\end{array}$ & $\begin{array}{l}\mathrm{N} \\
\mathrm{P}\end{array}$ & $\begin{array}{l}\mathrm{NP} \\
\mathrm{t}\end{array}$ & $\begin{array}{l}\mathrm{N} \\
\mathrm{V}\end{array}$ & $\begin{array}{l}\mathrm{S} \\
\mathrm{V}\end{array}$ & $\begin{array}{l}\text { Do } \\
\text { P }\end{array}$ & SVi & $\begin{array}{l}\mathrm{T} \\
\mathrm{U}\end{array}$ \\
\hline Alexander Bay & 10 & - & - & - & - & - & - & - & - & - & - & - & - & - & - & - & - \\
\hline Aliwal North & 10 & - & - & - & - & - & - & - & - & - & 5 & 1 & - & - & - & 10 & - \\
\hline Augrabies & 10 & 6 & - & - & - & - & - & - & - & - & - & - & - & - & - & - & - \\
\hline Beaufort West & 10 & 4 & - & - & - & - & - & - & - & - & - & - & - & - & - & - & - \\
\hline Bloemfontein & 16 & 10 & - & - & - & - & - & - & - & - & - & - & - & - & - & 22 & 21 \\
\hline Bloemhof & 10 & 7 & - & - & - & - & - & - & - & - & - & - & - & - & - & 5 & - \\
\hline Calitzdorp & 10 & - & - & - & - & - & - & - & - & - & - & 2 & - & - & - & - & - \\
\hline CapeTown & 7 & 5 & - & - & - & - & 3 & - & - & - & - & - & - & 1 & - & 5 & - \\
\hline Delareyville & 40 & 72 & - & - & - & - & - & - & - & - & - & - & - & - & - & 25 & - \\
\hline Graaff Reinet & 10 & 4 & - & - & - & - & - & - & 3 & - & - & - & - & - & - & - & - \\
\hline Haga Haga & 40 & - & - & - & - & 15 & - & - & 6 & - & - & - & - & - & - & - & - \\
\hline Hondeklipbaai & 10 & 10 & - & - & - & - & - & - & 3 & - & - & - & - & - & - & - & - \\
\hline Jansenville & 10 & 10 & - & - & - & - & - & - & - & - & - & - & - & - & - & - & - \\
\hline Kimberley & 10 & - & - & - & - & - & - & - & - & - & - & - & - & - & - & - & - \\
\hline Kuruman & 30 & 54 & - & - & - & - & - & - & - & - & - & - & 4 & - & - & 35 & - \\
\hline Wasbank & 20 & - & - & - & - & - & - & - & - & - & - & - & 10 & - & - & 12 & - \\
\hline Mokopane & 15 & 6 & 1 & 1 & - & - & 2 & 3 & - & - & - & - & - & - & - & - & - \\
\hline Prieska & 10 & - & - & - & - & - & - & - & - & - & - & - & - & - & - & - & - \\
\hline Queenstown & 10 & 6 & - & - & - & - & - & - & - & - & - & - & - & - & - & - & - \\
\hline Robertson & 10 & - & - & - & - & - & - & - & - & - & - & - & - & - & - & 8 & - \\
\hline Touws River & 10 & - & - & - & - & - & - & - & - & - & - & - & - & - & - & - & - \\
\hline Upington & 10 & 7 & - & - & - & - & - & - & - & - & - & - & - & - & - & - & - \\
\hline${ }^{\mathrm{a}} \mathrm{TM}$ (2008) & 40 & 8 & - & - & - & - & - & - & 8 & - & 16 & - & 25 & - & - & 53 & - \\
\hline${ }^{\mathrm{a}}$ TM (2009) & 40 & - & - & - & - & - & $\begin{array}{l}1 \\
4\end{array}$ & - & - & - & 23 & - & 28 & - & - & 28 & - \\
\hline${ }^{\mathrm{a}} \mathrm{TM}$ (2010) & 20 & - & - & - & - & - & 8 & - & - & 8 & 12 & - & 12 & - & - & 24 & - \\
\hline${ }^{\mathrm{b}} \mathrm{TM}$ & 40 & 6 & 10 & 3 & 8 & - & 8 & - & - & - & - & - & 11 & 3 & 2 & 140 & 3 \\
\hline
\end{tabular}

${ }^{\mathrm{a}} \mathrm{TM}$ : Tshwane Metropolitan area.

${ }^{\mathrm{b}}$ TM: The data from Jami et al., 2012 and Jami et al., 2013.

${ }^{c}$ No. T: Number of sampled trees, BD: Botryosphaeria dothidea, DA: Diplodia allocellula, DoB: Dothiorella brevicollis, DoD: Do. dulcispinae, LG: Lasiodiplodia gonubiensis, LT: L. theobromae, LPt: L. pseudotheobromae, NA: Neofusicoccum australe, NK: N. kwambonambiense, NP: N. parvum, NPr: N. protearum, NV: N. vitifusiforme, SV: Sphaeropsis variabilis, DoP: Dothiorella pretoriensis, SVi: S. viticola, TU: Tiarosporella urbisrosarum. 


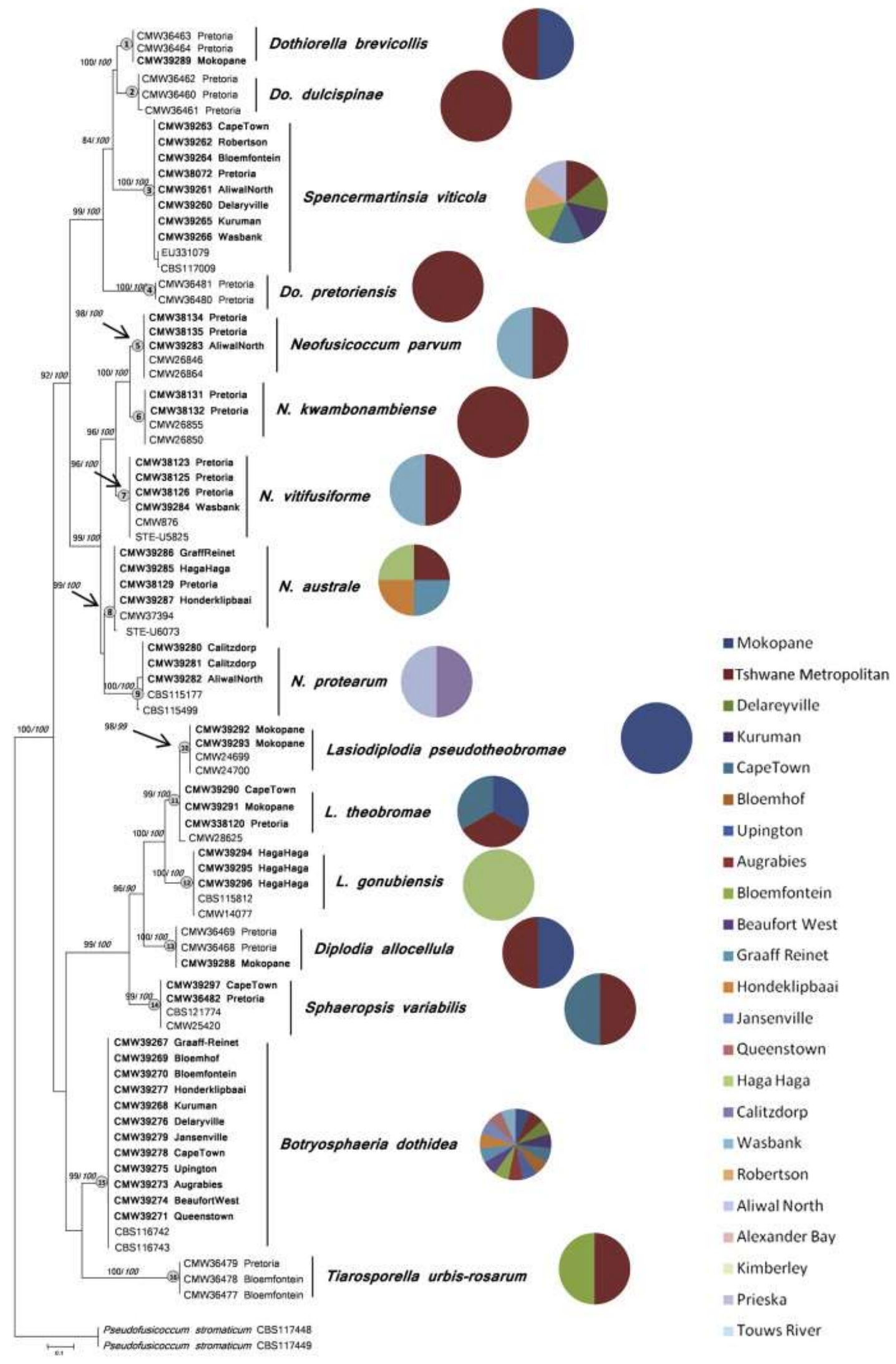

Fig 2 : Maximum Likelihood (ML) tree of the combined data set of ITS ribosomal DNA and TEF-1 $\alpha$ loci sequences. Bootstrap values of $>60 \%$ for $\mathrm{ML}$ (roman) and Maximum Parsimony (italic) are given at the nodes. The tree was rooted to Pseudofusicoccum stromaticum (CBS117448 and CBS117449). Isolates sequenced in this study are presented in bold. Pie charts indicate the sites from which the species were isolated. 


\section{DNA sequence analyses}

The datasets for the ITS and TEF-1 $\alpha$ sequences were analyzed individually and in combination. The ITS sequence dataset contained 522 characters ( 4 parsimonyuninformative, 148 parsimony-informative, 370 constant characters) with $\mathrm{Cl}=0.602, \mathrm{RI}=$ $0.902, \mathrm{RC}=0.543, \mathrm{HI}=0.398$ and $\mathrm{TL}=321$. The $T E F-1 \alpha$ dataset had 362 characters $(3$ parsimony-uninformative, 224 parsimony-informative, 135 constant characters) with $\mathrm{Cl}=$ $0.651, \mathrm{RI}=0.919, \mathrm{RC}=0.550, \mathrm{HI}=0.383$ and $\mathrm{TL}=986$. The tree statistics for the combined dataset (TreeBase Accession No. S12358) were $\mathrm{Cl}=0.487, \mathrm{RI}=0.854, \mathrm{RC}=0.416, \mathrm{HI}=0.513$, $\mathrm{TL}=2148$, and the partition homogeneity test $(\mathrm{PHT})$ on the datasets produced a $\mathrm{P}$-value of 0.01 . For $M L$ analyses, both datasets (individual gene regions and the combined analysis) fitted the best GTR model and had the following parameters: for ITS G $=0.337, I=0.468$, TEF- $1 \alpha \mathrm{G}=0.811, \mathrm{I}=0$ and for combined datasets $\mathrm{G}=0.663, \mathrm{I}=0.553$.

The topology of the trees obtained using the ML and MP analyses were similar with regard to the clades representing species isolated for the individual gene regions, as well as in the combined analysis. Isolates resided in eight genera and 13 species groups that were identified as B. dothidea, Spencermartinsia viticola, Diplodia allocellula, Dothiorella brevicollis, Sphaer-opsis variabilis, N. vitifusiforme, N. parvum, N. australe, $N$. kwambonambiense, N. protearum, Lasiodiplodia theobromae, L. pseudotheobromae, and L. gonubiensis. Three previously named species, Do. pretoriensis, Do. dulcispinae and Tiarosporella urbisrosarum (Jami et al., 2012, 2013) were included in the analyses (Fig 2). Botryosphaeria dothidea was isolated from trees at 14 sites and S. viticola was found at nine sites. These two species were the most commonly isolated taxa across the country and represented $44 \%$ and $26 \%$ of the total isolates, respectively (Fig 1 ). The frequency of $B$. dothidea isolates was higher than for the other species in most areas where this species was found (Fig 1). The frequency of S. viticola was higher than the other species in the Tshwane Metropolitan area (Gauteng), Bloemfontein (Free State), Wasbank (Kwazulu-Natal), Aliwal North (Eastern Cape) and Robertson (Western Cape) areas (Fig 1).

\section{Statistical analyses of species richness}

An $8 * 3$ contingency table was used, with species richness in rows (seven species, and an extra category where no species were found) and sampling years in columns. Under the null hypothesis it was assumed that species richness and sampling years were independent of one another. There was a statistically significant relationship between species rich-ness and years of sampling (Fisher's exact test, P-value $=0.0005$ ). Some species were observed in particular years, but not in others. For example, N. parvum, N. vitifusi-forme, S. viticola and L. theobromae were isolated in two or more years, and B. dothidea, N. australe and $N$. kwambonambiense were isolated in only one of the three years (Fig 3). Spencermartinsia viticola was dominant in all three years, representing $46.9 \%$ (2008), $28.4 \%$ (2009) and 37.5 $\%$ (2010) of the total number of isolates (Fig 3). 
There was a statistically significant relationship between tissue and species richness over the three years of sampling (Fisher's exact test, $P$-value $=0.0005$ ). The species richness from branches was significantly higher in the second year than the other two years of sampling (Fisher's exact test, $P$-value $=0.0005)$, while species richness from leaves was significantly higher in the second and third year compared to the first year of sampling (Fisher's exact test, $P$-value $=0.0005)$. The species richness from branchlets was significantly higher in the first year compared to the other years (Fisher's exact test, $P$-value $=0.0002$ ). Overall, the species richness from leaves was significantly higher com-pared to branchlets and branches

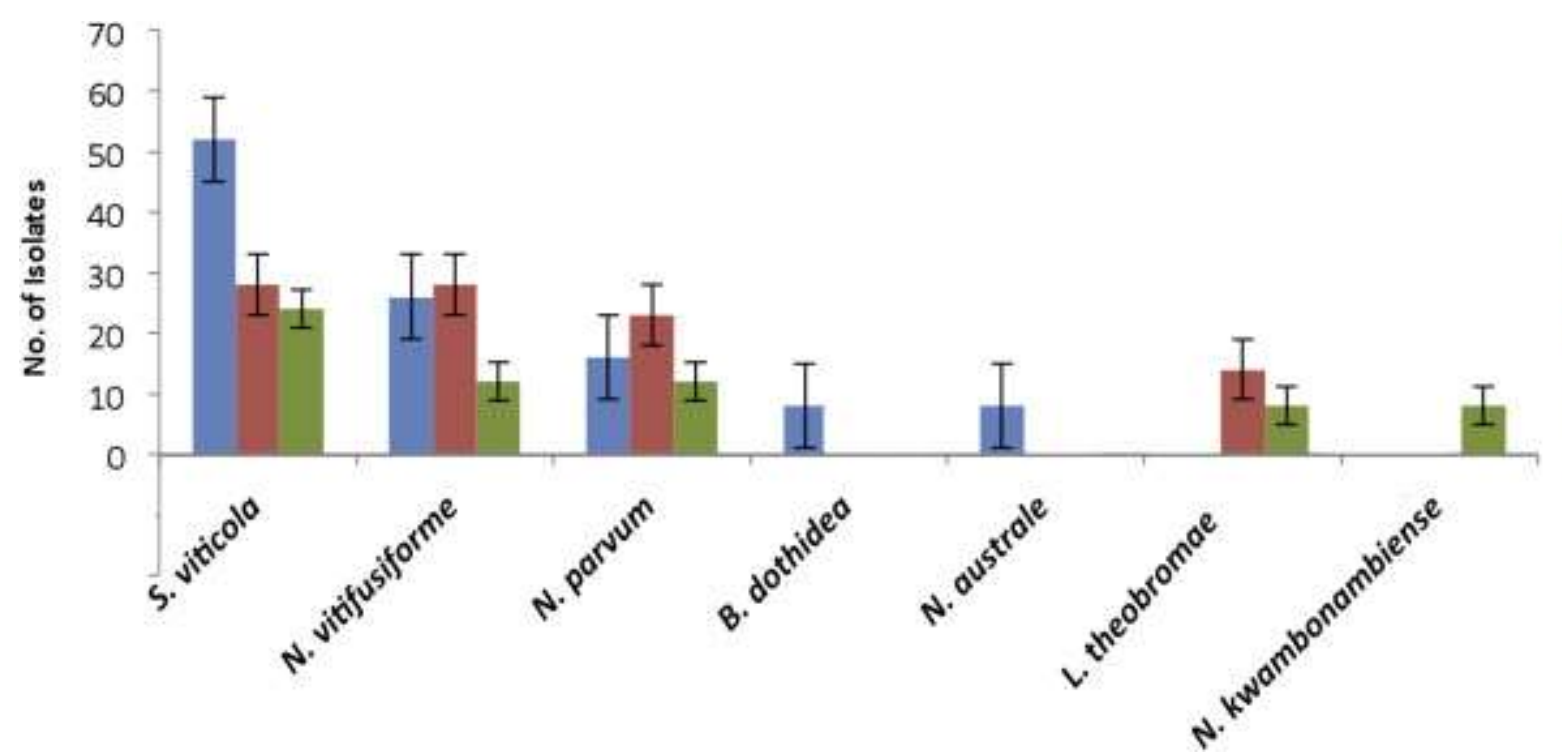

Fig 3 : Species richness of Botryosphaeriaceae on Acacia karroo for each year sampled in the greater Tshwane Metropolitan area. Bars indicate standard error.

(Fisher's exact test, $P$-value $=0.0005)$. The more common species, S. viticola, $N$. vitifusiforme, N. parvum and L. theobromae, were isolated from all tissue types. However, the more rarely occurring species were found only in certain tissues. For example, $N$. australe was found only in leaves and branchlets, $B$. dothidea only in branchlets and $N$. kwambonambiense only in branches (Fig 4). Spencermartinsia viticola was significantly more common in branches and leaves than in branchlets (Fisher's exact test, $P$-value $=0.0005$ ), while $N$. vitifusiforme was significantly more common in branchlets (Fisher's exact test, $P$ value $=0.0024$ ). 


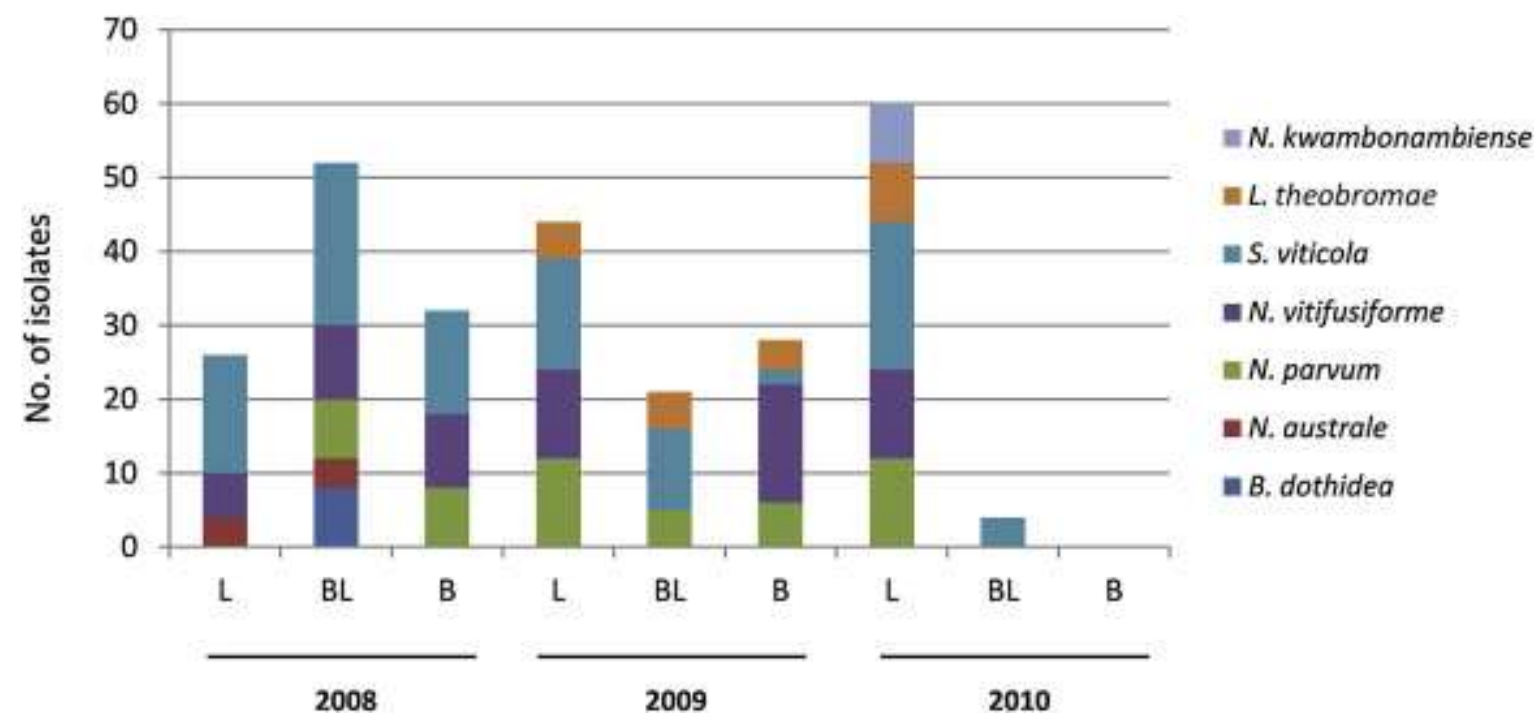

Fig 4 : Species richness of Botryosphaeriaceae on leaves (L), branchlets (BL) and branches (B) of Acacia karroo for 2008, 2009 and 2010.

Results of the k-sample Anderson Darling test, comparing monthly means for maximum and minimum temperature, precipitation, humidity and sunlight hours, showed no significant differences among these climate features for the three sampling years. In none of these cases could the null hypothesis be rejected, under which the climate features could have originated from a common distribution. Rarefaction curves for all 23 sites (including the Tshwane Metropolitan area) showed that location affected the species richness as much as sampling intensity did. Trees at sites such as Tshwane Metropolitan area more frequently yielded isolates for the same number of samples taken from other sites (Fig 5). The species richness curve for Tshwane Metropolitan data was much steeper than that for any other site (Fig 5). 

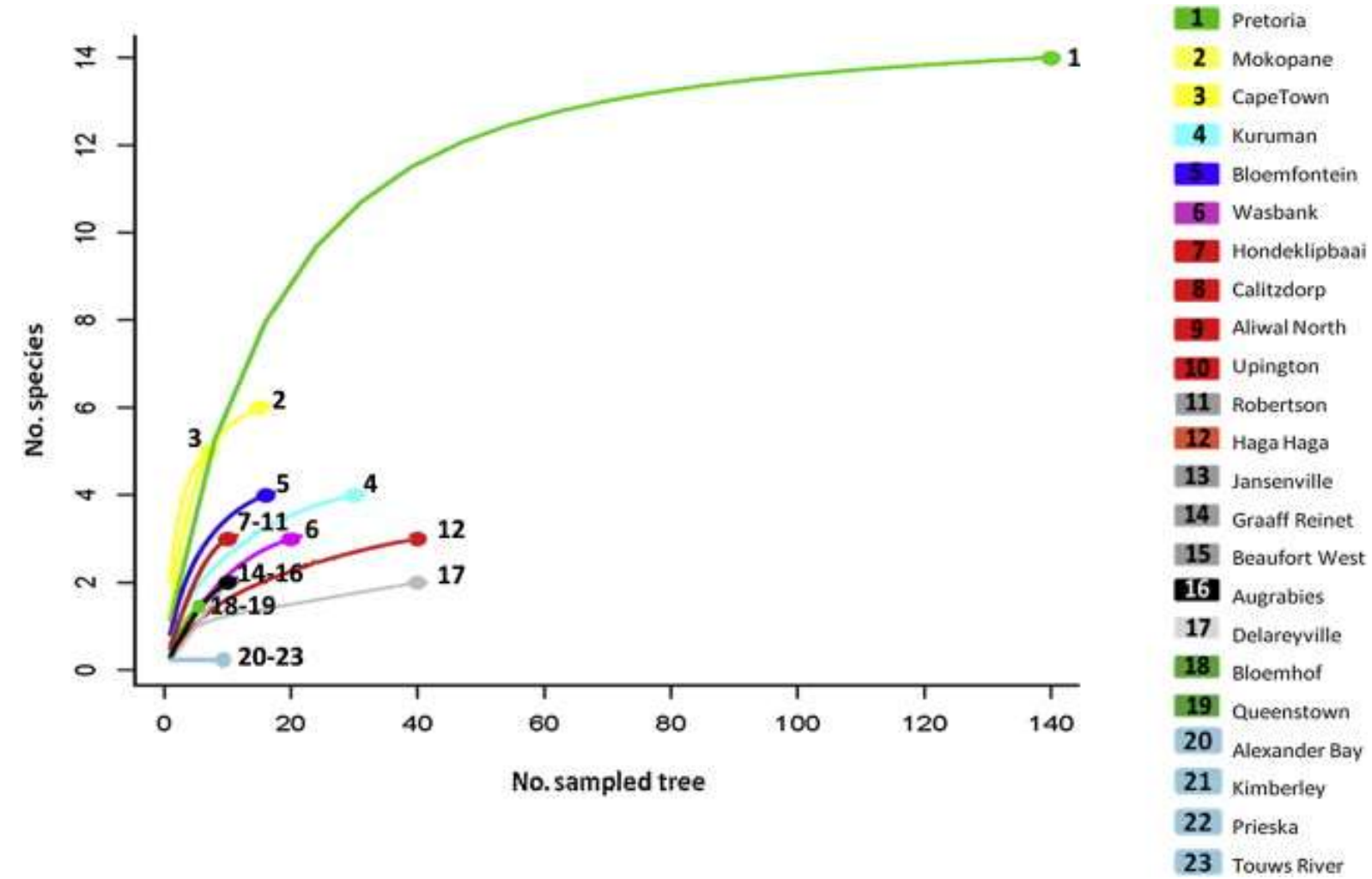

Fig 5 : Rarefaction analysis for sampled trees demonstrating that the sampling intensity did not affect the species richness as much as location did. Trees at sites such as Tshwane Metropolitan area more frequently yielded isolates for the same number of samples taken from other sites.

\section{Pathogenicity tests}

All 37 isolates representing the 13 species produced lesions in the cambium of inoculated branches within 6 weeks while no lesions were observed for the control inoculations (Fig 6). Statistical analyses (including data from Jami et al., 2013) showed that lesion size for the different fungi varied little between replicate trees inoculated per isolate, but varied considerably between isolates for certain species, including those of $B$. dothidea, $N$. australe, Do. brevicollis, T. urbis-rosarum and S. viticola. The longest lesions were produced by S. variabilis $(\bar{X}=27.7 \mathrm{~mm})$, L. theobromae $(\bar{X}=26.3 \mathrm{~mm}), N$. parvum $(\bar{X}=20.6 \mathrm{~mm})$ and $N$. australe $(\bar{X}=18.3 \mathrm{~mm})$. All 13 Botryosphaeriaceae species were re-isolated from lesions and no Botryosphaeriaceae were isolated from the controls. They were identified based on cultural and conidial morphology. 


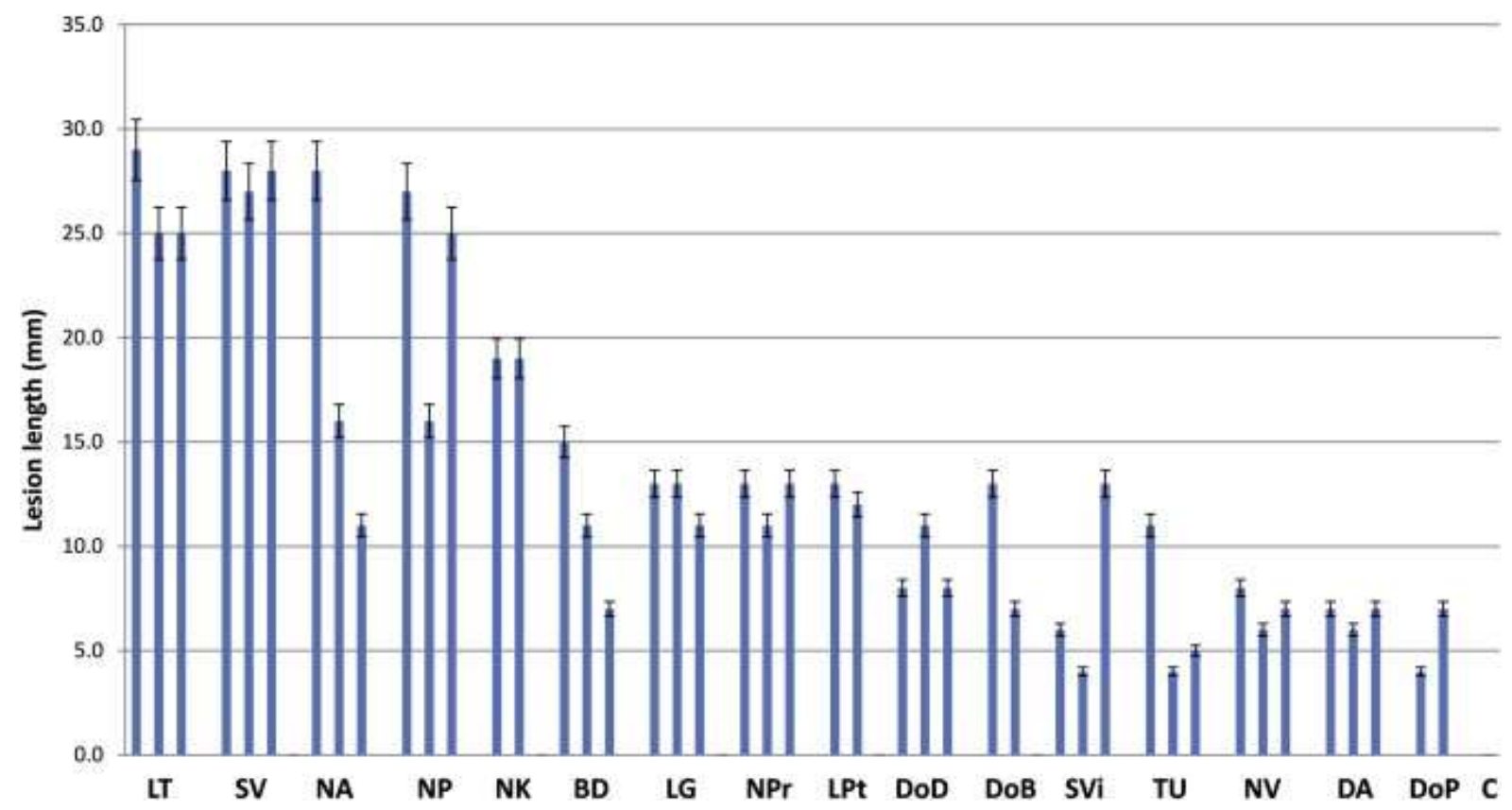

Fig 6 : Mean lesion length $(\mathrm{mm})$ for species of Botryosphaeriaceae six weeks after inoculation on Acacia karroo. LT: Lasiodiplodia theobromae, SV: Sphaeropsis variabilis, NA: Neofusicoccum australe, NP: N. parvum, NK: N. kwambonambiense, BD: Botryosphaeria dothidea, LG: L. gonubiensis, NPr: N. protearum, LPt: L. pseudotheobromae, DoD: Dothiorella dulcispinae, DoB: Do. brevicollis, SVi: Spencermartinsia viticola, TU: Tiarosporella urbis-rosarum, NV: N. vitifusiforme, DA: Diplodia allocellula, DoP: Do. pretoriensis, C: Control. Multiple bars for a species represent individual isolates and bars indicate standard error.

\section{Discussion}

In this study, eight genera and 13 species of Botryosphaeriaceae were found in healthy $A$. karroo trees sampled broadly across South Africa. Thus, a total of 16 species residing in eight genera, including those previously recorded (Jami et al., 2012, 2013), are known from this tree species. Of these genera, the most frequently encountered were Botryosphaeria, Spencermartinsia and Neofusicoccum, representing $44 \%(n=184), 27 \%(n=112)$ and $15 \%$ ( $n=61)$, respectively, of the total number of isolates. Diplodia (1\%), Sphaeropsis (2\%), Dothiorella (2\%), Tiarosporella (5\%) and Lasiodiplodia (5\%) are apparently less frequent genera. Apart from clear patterns of dominance in the community of Botryosphaeriaceae across South Africa, this study also revealed that this diversity varied across time and space (both between sites and among different tree tis-sues on individual trees).

Sampling over 3 years at one site (Tshwane Metropolitan area), revealed seven species of Botryosphaeriaceae, but no significant variation in species richness between sampling years. Spencermartinsia viticola, N. parvum and $N$. vitifusiforme were present in all three sampling years, while $N$. australe and $B$. dothidea were found only in the first year, $N$. kwambonambiense only in the third year and L. theobromae in the second and third year. Climatic factors did not vary significantly across the sites over this time. Furthermore, potential spatial effects were minimized by sampling from the same locations and trees 
between years. These results provide a useful foundation for future sampling efforts in areas with fairly stable weather conditions over time.

Botryosphaeria dothidea was the most common species encountered in the country-wide survey of $A$. karroo, being isolated from 14 sites. Botryosphaeria dothidea is one of the most globally widespread species in the Botryosphaeriaceae (Slippers and Wingfield, 2007) and its dominance in $A$. karroo is, therefore, not surprising. In previous South African studies, $B$. dothidea has been isolated from nine woody plants occurring in different areas (KwaZuluNatal, Mpumalanga and Eastern Cape) of the country (Pavlic et al., 2007; Roux et al., 1997; Smith et al., 2001). Botryosphaeria dothidea was first described from Europe, where it has been considered native given its high diversity, wide occurrence, and association with local hosts (Piskur et al., 2011; Slippers et al., 2004a; Slippers and Wingfield, 2007). Subsequent to those studies, the fungus has been found in many different parts of the world (Slippers and Wingfield, 2007). It is clear that $B$. dothidea is a very successful invader and colonist of both native and non-native trees, and in a wide range of environments including relatively undisturbed as well as intensively managed areas.

Spencermartinsia viticola was the second most isolated species of Botryosphaeriaceae on $A$. karroo in South Africa. This fungus has also commonly been isolated from A. mellifera in Pretoria (Gauteng) (Slippers et al., 2014) and Vitis vinifera in Stellenbosch (Western Cape) (Van Niekerk et al., 2004). Like-wise, Jami et al. (2013) found that S. viticola was the most common species among the eight isolated from A. karroo in the Tshwane Metropolitan area. Its common occurrence on $A$. karroo in the present study supports previous findings that this tree appears to be a particularly common host for this fungus. Neofusicoccum australe was isolated from $A$. karroo trees growing at four sites, including a wide variety of environments, ranging from desert to warm temperate and humid climates. It has previously been reported from S. cordatum in the Eastern Cape (Pavlic et al., 2004), grape, pome and stone fruit trees in the Western Cape (Van Niekerk et al., 2004; Damm et al., 2007; Slippers et al., 2007) and Eucalyptus in Mtubatuba in northern KwaZulu-Natal (Pillay et al., 2013). Neofusicoccum australe is particularly well known in Western Australia, which has a Mediterranean climate with hot and dry summers and cool, wet winters (Burgess et al., 2006b; Cunnington et al., 2007; Taylor et al., 2009).

Lasiodiplodia pseudotheobromae represents another example of a broadly distributed species, but that was rarely isolated in the present study. Here it was isolated from trees in the Tshwane Metropolitan (Gauteng) and Mokopane (Gauteng and Limpopo provinces) but in previous studies it has been collected from Pterocarpus spp. (Mawewe Nature Reserve, Mpu-malanga), T. catappa (Richardsbay, KwaZulu-Natal) and S. cordatum (Mtubatuba, KwaZulu-Natal) in South Africa (Begoude et al., 2010; Mehl et al., 2011; Pillay et al., 2013). Climate appears to provide an explanation regarding the distribution of $L$. pseudotheobromae, whereas this seems not to be the case for other rarely occurring species. This species is common in tropical parts of Africa and South America (Alves et al., 
2008; Ismail et al., 2012; Castro Medina et al., 2013; Marques et al., 2013). While it is possible that $A$. karroo is not a primary host for this fungus, it is more likely that it does not occur in the drier and colder areas sampled in the study. The same would be true for $L$. theobromae (Punithalingam, 1980; Alves et al., 2008) and N. kwambonambiense, both known from tropical areas of the world (Sakalidis et al., 2013) but that were rare in this study.

Other species of the Botryosphaeriaceae isolated in this and previous studies from A. karroo were found at only a few sites. These were normally in close proximity to each other, or were from urban centers such as Tshwane Metropolitan area. Neofusicoccum parvum was collected in Tshwane Metropolitan area (Gauteng) and Aliwal-North (Western Cape), but it is also known from T. catappa in Richardsbay (KwaZulu-Natal), S. cordatum in Kwambonambi (KwaZulu-Natal), Prunus domestica in Villiersdorp (Western Cape), and V. vinifera in Stellenbosch (Western Cape) (Van Niekerk et al., 2004; Pavlic et al., 2007; Slippers et al., 2007; Begoude et al., 2010). Based on these and other studies, Sakalidis et al. (2013) suggested that $N$. parvum might be native to South Africa. Despite its wide-spread and common occurrence in the country on other hosts such as Eucalyptus spp., Syzygium spp., Terminalia spp. and $V$. vinifera, it appears to be more rare on $A$. karroo.

Apart from the examples treated above, a number of other species were described in this study from areas and tree hosts ( $A$. karroo) for the first time. For example, N. protearum was previously known only from Protea spp. in the Western Cape (Denman et al., 2003; Marincowitz et al., 2008b), while in the present study it was found on A. karroo in Alliwal North (Eastern Cape) and Calitzdorp (Western Cape). Neofusicoccum vitifusiforme is reported in the present study from A. karroo in Tshwane Metropolitan (Gauteng) and Wasbank (KwaZulu-Natal), while it has previously been found on $V$. vinifera and $P$. salicina in the Western Cape and Modimolle (Limpopo) (Van Niekerk et al., 2004; Damm et al., 2007). Sphaeropsis variabilis was found from Tshwane Metropolitan (Gauteng) and Cape Town (Western Cape) in the present survey, and has previously been described from A. hebeclada, A. mellifera and A. karroo in Namibia and South Africa (Jami et al., 2013; Slippers et al., 2014). This shows that they may be more widely distributed than originally thought, and published records of their distribution are significantly influenced by the fact that they are easily overlooked in small samples.

The distribution data indicate possible endemism for some Botryosphaeriaceae in South Africa. Some species such as Do. pretoriensis are thus far known only from a single area (Jami et al., 2012, 2013). Lasiodiplodia gonubiensis was isolated only from the Eastern Cape, the same region from which it was originally described on S. cordatum (Pavlic et al., 2004). Whether these represent locally adapted, endemic species, or whether the results reflect depth of sampling for rare species, remains to be clarified. In the case of $L$. gonubiensis, which has been repeatedly found in this area, but nowhere else, endemism appears to be an increasingly likely explanation. 
The diversity of Botryosphaeriaceae species varied among the tissues types (leaves, branchlets, branches) over the $3 \mathrm{yr}$, but not in a consistent pattern. The only significant pattern was that the species richness on branches and branchlets was significantly different over the $3 \mathrm{yr}$. For example, in the third year, the species richness was significantly higher among leaves, branches and branchlets, but this was not the case for the first and second year. Furthermore, specific species could not be linked to specific tissues and common species occurred on all tissues. Rare species occurred in fewer tissue types, but together with information from other studies also do not appear to be tissue specific. For example, $\mathrm{N}$. kwambonambiense was found only on leaves in this study, but previously has been found on branches and fruits of S. cordatum (Pavlic et al., 2009) and branches of Eucalyptus grandis (Pillay et al., 2013). It is not clear whether broader and denser sampling will result in higher species richness. However, sampling could target any of these tissues. In terms of frequency and practicality, sampling from branches would be easiest.

In the present survey, the species richness was higher in the Tshwane Metropolitan area than elsewhere, even after correcting for sampling intensity. Interestingly, the isolation frequency per tree in the Tshwane Metropolitan area was also higher than the other sampled sites. It is not clear what drives this increased diversity, but one possibility is that the higher plant diversity in the urban areas (introduced for horticulture) together with the higher frequency of trade (with Pretoria as one of the main urban centres in the country) compared to other sampled sites could influence the surrounding diversity in Botryosphaeriaceae. There could be other factors, such as intense human activity and pollution, that influence this pattern of diversity (Slippers and Wingfield, 2007). This would be a fruitful area to explore in future, especially with a view to understanding the potential influence of urban centers such as Pretoria as reservoirs or "biological bridges" for invasive fungi.

Comprehensive geographical surveys exist for numerous animal and plant species in South Africa. Although these distribution data are not complete in all cases, they are adequate to show patterns of occurrence, and links to ecological function, diversity, areas of endemism and conservation priorities for these taxa. Such information is very limited for fungi, even for important groups of plant-associated fungi such as endophytes or latent pathogens, because of the difficulty of acquiring relatively complete data. This study, together with a growing number of similar studies of fungi on native hosts in South Africa (Marincowitz et al., 2008a), provides foundations on which a greater number of inventories and sampling efforts can be based.

\section{Acknowledgments}

We thank Prof. Jolanda Roux, Dr. Tanya Joffe and Mrs. Elsie Cruywagen assisting us with sample collection. Members of the Tree Protection Cooperative Programme (TPCP), the DST/NRF Centre of Excellence in Tree Health Biotechnology (CTHB) and the University of Pretoria, South Africa are acknowledged for financial support. 


\section{References}

Alves, A., Crous, P.W., Correia, A., Phillips, A.J.L., 2008. Morphological and molecular data reveal cryptic speciation in Lasiodiplodia theobromae. Fungal Diversity 28, 1-13.

Begoude, B.A.D., Slippers, B., Wingfield, M.J., Roux, J., 2010. Botryosphaeriaceae associated with Terminalia catappa in Cameroon, South Africa and Madagascar. Mycological Progress 9, 101-123.

Burgess, T.I., Barber, P.A., Mohali, S., Pegg, G., de Beer, W., Wingfield, M.J., 2006a. Three new Lasiodiplodia spp. from the tropics, recognized based on DNA sequence comparisons and morphology. Mycologia 98, 423.

Burgess, T.I., Sakalidis, M.L., Hardy, G.E.S.J., 2006b. Gene flow of the canker pathogen Botryosphaeria australis between Eucalyptus globulus plantations and native eucalypt forests in Western Australia. Austral Ecology 31, 559-566.

Carbone, I., Kohn, L.M., 1999. A method for designing primer sets for speciation studies in filamentous ascomycetes. Mycologia 91, 553-556.

Castro Medina, F., Mohali, S.R., Urbez-Torres, J.R., Gubler, W.D., 2013. First report of Lasiodiplodia pseudotheobromae causing trunk cankers in Acacia mangium in Venezuela. Plant Disease, 1-5.

Cunnington, J.H., Priest, M.J., Powney, R.A., Cother, N.J., 2007. Diversity of Botryosphaeria species on horticultural plants in Victoria and New South Wales. Australasian Plant Pathology 36, 157-159.

Damm, U., Crous, P.W., Fourie, P.H., 2007. Botryosphaeriaceae as potential pathogens of Prunus species in South Africa, with descriptions of Diplodia africana and Lasiodiplodia plurivora sp. nov. Mycologia 99, 664-680.

De Abreu, L.M., Almeida, A.R., Salgado, M., Pfenning, L.H., 2010. Fungal endophytes associated with the mistletoe Phoradendron perrottettii and its host tree Tapirira guianensis. Mycological Progress 9, 559-566.

Denman, S., Crous, P.W., Groenewald, J.Z., Slippers, B., Wingfield, B.D., Wingfield, M.J., 2003. Circumscription of Botryosphaeria species associated with Proteaceae based on morphology and DNA sequence data. Mycologia 95, 294-307.

Farris, J.S., Kallersjo, M., Kluge, A.G., Bult, C., 1995. Testing significance of incongruence. Cladistics 10, 315-319.

Fisher, R.A., 1970. Statistical Methods for Research Workers. Oliver \& Boyd. 
Gardes, M., Bruns, T.D., 1993. ITS primers with enhanced specificity for basidiomycetes application to the identification of mycorrhizae and rusts. Molecular Ecology 2, 113-118.

Gazis, R., Chaverri, P., 2010. Diversity of fungal endophytes in leaves and stems of wild rubber trees (Hevea brasiliensis) in Peru. Fungal Ecology 3, 240-254.

Gond, S.K., Verma, V.C., Kumar, A., Kumar, V., Kharwar, R.N., 2007. Study of endophytic fungal community from different parts of Aegle marmelos Correae (Rutaceae) from Varanasi (India). World Journal of Microbiology and Biotechnology 23, 1371-1375.

Hillis, D.M., Huelsenbeck, J.P., 1992. Signal, noise, and reliability in molecular phylogenetic analyses. Journal of Heredity 83, 189-195.

Hsieh, T.C., Ma, K.H., Chao, A., 2013. iNEXT Online: Interpolation and Extrapolation (Version 1.3.0) [Software]. Available from: http://chao.stat.nthu.edu.tw/blog/software-download/.

Huang, W.Y., Cai, Y.Z., Hyde, K.D., Corke, H., Sun, M., 2008. Biodiversity of endophytic fungi associated with 29 traditional Chinese medicinal plants. Fungal Diversity 33, 61-75.

Huelsenbeck, J.P., Bull, J.J., Cunningham, C.W., 1996. Combining data in phylogenetic analysis. Trends in Ecology \& Evolution 11, 152-158.

Ismail, A.M., Cirvilleri, G., Polizzi, G., Crous, P.W., Groenewald, J.Z., Lombard, L., 2012. Lasiodiplodia species associated with dieback disease of mango (Mangifera indica) in Egypt. Australasian Plant Pathology 41, 649-660.

Jami, F., Slippers, B., Wingfield, M.J., Gryzenhout, M., 2012. Five new species of the Botryosphaeriaceae from A. karroo in South Africa. Cryptogamie Mycologie 33, 245-266.

Jami, F., Slippers, B., Wingfield, M.J., Gryzenhout, M., 2013. Greater Botryosphaeriaceae diversity in healthy than associated diseased $A$. karroo tree tissues. Australasian Plant Pathology 42, 421-430.

Jami, F., Slippers, B., Wingfield, M.J., Gryzenhout, M., 2014. Botryosphaeriaceae species overlap on four unrelated, native South African hosts. Fungal Biology 118, 168-179.

Katoh, K., Kuma, K., Toh, H., Miyata, T., 2005. MAFFT version 5: improvement in accuracy of multiple sequence alignment. Nucleic Acids Research 33, 511.

Kharwar, R.N., Verma, V.C., Strobel, G., Ezar, D., 2008. The endophytic fungal complex of Catharanthus roseus (L.) G. Don. Current Science 95, 228-233.

Lee, S.B., Taylor, J.W., 1990. Isolation of DNA from fungal mycelia and single spores. In: Innis, M.A., Gelfand, D.H., Sninsky, J.J., White, T.J. (Eds.), PCR Protocols. A Guide to Methods and Applications. Academic Press, San Diego, Calif, pp. 282-287. 
Lu, G., Moriyama, E.N., 2004. Vector NTI, a balanced all-in-one sequence analysis suite. Briefings in Bioinformatics 5, 378-388.

Luque, J., Martos, S., Phillips, A.J.L., 2005. Botryosphaeria viticola sp. nov. on grapevines: a new species with a Dothiorella anamorph. Mycologia 97, 1111-1121.

Marincowitz, S., Crous, P.W., Groenewald, J.Z., Wingfield, M.J., 2008a. Microfungi Occurring on Proteaceae in the Fynbos. CBS Fungal Biodiversity Centre, Utrecht, Netherlands.

Marincowitz, S., Groenewald, J.Z., Wingfield, M.J., Crous, P.W., 2008b. Species of Botryosphaeriaceae occurring on Proteaceae. Persoonia: Molecular Phylogeny and Evolution of Fungi 21, 111-118.

Marques, M.W., Lima, N.B., de Morais Jr., M.A., Michereff, S., Phillips, A.J.L., Câmara, M.P.S., 2013. Botryosphaeria, Neofusicoccum, Neoscytalidium and Pseudofusicoccum species associated with mango in Brazil. Fungal Diversity 61, 195-208.

Mehl, J.W.M., Slippers, B., Roux, J., Wingfield, M.J., 2011. Botryosphaeriaceae associated with Pterocarpus angolensis (kiaat) in South Africa. Mycologia 103, 534-553.

Mishra, A., Gond, S.K., Kumar, A., Sharma, V.K., Verma, S.K., Kharwar, R.N., Sieber, T.N., 2012. Season and tissue type affect fungal endophyte communities of the Indian medicinal plant Tinospora cordifolia more strongly than geographic location. Microbial Ecology 64, 388-398.

Pavlic, D., Slippers, B., Coutinho, T.A., Gryzenhout, M., Wingfield, M.J., 2004. Lasiodiplodia gonubiensis sp. nov., a new Botryosphaeria anamorph from native Syzygium cordatum in South Africa. Studies in Mycology 50, 313-322.

Pavlic, D., Slippers, B., Coutinho, T.A., Wingfield, M.J., 2007. Botryosphaeriaceae occurring on native Syzygium cordatum in South Africa and their potential threat to Eucalyptus. Plant Pathology 56, 624-636.

Pavlic, D., Slippers, B., Coutinho, T.A., Wingfield, M.J., 2009. Multiple gene genealogies and phenotypic data reveal cryptic species of the Botryosphaeriaceae: a case study on the Neofusicoccum parvum/N. ribis complex. Molecular Phylogenetics and Evolution 51, 259268.

Phillips, A.J.L., Alves, A., Correia, A., Luque, J., 2005. Two new species of Botryosphaeria with brown, 1-septate ascospores and Dothiorella anamorphs. Mycologia 97, 513-529.

Phillips, A.J.L., Alves, A., Pennycook, S.R., Johnston, P.R., Ramaley, A., Akulov, A., Crous, P.W., 2008. Resolving the phylogenetic and taxonomic status of dark-spored teleomorph genera in the Botryosphaeriaceae. Persoonia: Molecular Phylogeny and Evolution of Fungi 21, 29-55. 
Pillay, K., Slippers, B., Wingfield, M.J., Gryzenhout, M., 2013. Diversity and distribution of coinfecting Botryosphaeriaceae from Eucalyptus grandis and Syzygium cordatum in South Africa. South African Journal of Botany 84, 38-43.

Piskur, B., Pavlic, D., Slippers, B., Ogris, N., Maresi, G., Wingfield, M.J., Jurc, D., 2011. Diversity and pathogenicity of Botryosphaeriaceae on declining Ostrya carpinifolia in Slovenia and Italy following extreme weather conditions. European Journal of Forest Research 130, 235-249.

Posada, D., Buckley, T.R., 2004. Model selection and model averaging in phylogenetics: advantages of Akaike information criterion and Bayesian approaches over likelihood ratio tests. Systematic Biology 53, 793-808.

Punithalingam, E., 1980. Plant diseases attributed to Botryodiplodia theobromae. In: Biblioteca Mycologica. J. Cramer, Berlin, Germany.

Roux, J., Wingfield, M.J., Morris, M.J., 1997. Botryosphaeria dothidea as a pathogen of Acacia mearnsii in South Africa. South African Journal of Science 99, 327-336.

Sakalidis, M.L., Slippers, B., Wingfield, B.D., Hardy, G.E.S.J., Burgess, T.I., 2013. The challenge of understanding the origin, pathways and extent of fungal invasions: global populations of the Neofusicoccum parvumeN. ribis species complex. Diversity and Distributions 19, 8731094.

Scholz, F., Zhu, A., 2012. kSamples: K-sample Rank Tests and Their Combinations. R package version 1.0. http://CRAN. R-project.org/package=kSamples.

Shamoun, S.F., Sieber, T.N., 2000. Colonisation of leaves and twigs of Rubus parviflorus and $R$. spectabilis by endophytic fungi in a reforestation site in British Columbia. Mycological Research 104, 841-845.

Slippers, B., Crous, P.W., Denman, S., Coutinho, T.A., Wingfield, B.D., Wingfield, M.J., 2004a. Combined multiple gene genealogies and phenotypic characters differentiate several species previously identified as Botryosphaeria dothidea. Mycologia 96, 83-101.

Slippers, B., Fourie, G., Crous, P.W., Coutinho, T.A., Wingfield, B.D., Carnegie, A.J., Wingfield, M.J., 2004b. Speciation and distribution of Botryosphaeria spp. on native and introduced Eucalyptus trees in Australia and South Africa. Studies in Mycology, 343-358.

Slippers, B., Roux, J., Wingfield, M.J., Van der Walt, F.J.J., Jami, F., Mehl, J.W.M., Marais, G., 2014. Confronting the constraints of morphological taxonomy in the fungi: a Botryosphaeriaceae case study. Persoonia 33, 155-168.

Slippers, B., Smit, W.A., Crous, P.W., Coutinho, T.A., Wingfield, B.D., Wingfield, M.J., 2007. Taxonomy, phylogeny and identification of Botryosphaeriaceae associated with pome and stone fruit trees in South Africa and other regions of the world. Plant Pathology 56, 128-139. 
Slippers, B., Wingfield, M.J., 2007. Botryosphaeriaceae as endophytes and latent pathogens of woody plants: diversity, ecology and impact. Fungal Biology Reviews 21, 90e106.

Smith, H., Crous, P.W., Wingfield, M.J., Coutinho, T.A., Wingfield, B.D., 2001. Botryosphaeria eucalyptorum sp. nov., a new species in the $B$. dothidea complex on Eucalyptus in South Africa. Mycologia 93, 277-285.

Swart, W.J., Wingfield, M.J., 1991. Biology and control of Sphaeropsis sapinea on Pinus species in South Africa. Plant Disease 75, 761-766.

Swofford, D.L., 2001. PAUP. Phylogenetic Analysis Using Parsimony (And Other Methods). Version 4. Sinaur Associates, Sunderland, Mass., USA.

Tamura, K., Dudley, J., Nei, M., Kumar, S., 2007. MEGA4: molecular evolutionary genetics analysis (MEGA) software version 4.0. Molecular Biology and Evolution 24, 1596-1599.

Taylor, J.E., Hyde, K.D., Jones, E.B.G., 1999. Endophytic fungi associated with the temperate palm, Trachycarpus fortunei, within and outside its natural geographic range. New Phytologist 142, 335-346.

Taylor, K., Barber, P.A., Hardy, G.E.S.J., Burgess, T.I., 2009. Botryosphaeriaceae from tuart (Eucalyptus gomphocephala) woodland, including descriptions of four new species. Mycological Research 113, 337-353.

Van Niekerk, J.M., Crous, P.W., Groenewald, J.Z., Fourie, P.H., Halleen, F., 2004. DNA phylogeny, morphology and pathogenicity of Botryosphaeria species on grapevines. Mycologia 96, 781-798.

VanWyk, B., VanWyk, P., 1997. Field Guide to the Trees of Southern Africa. Struik Publishers, Cape Town, South Africa.

White, T.J., Bruns, T., Lee, S., Taylor, J., 1990. Amplification and direct sequencing of fungal ribosomal RNA genes for phylogenetics. In: Innis, M.A., Gelfand, D.H., Sninsky, J.J., White, T.J. (Eds.), PCR Protocols: A Guide to Methods and Applications. Academic Press, New York, pp. 315-322.

Yuan, Z., Chen, Y., Yang, Y., 2009. Diverse non-mycorrhizal fungal endophytes inhabiting an epiphytic, medicinal orchid (Dendrobium nobile): estimation and characterization. World Journal of Microbiology and Biotechnology 25, 295-303. 